\title{
Remobilization in aquatic medium of rat soleus immobilized in lengthening
}

\author{
MEIRELES, A. ${ }^{1,2}$, ROCHA, B. P. $^{2}$, SILVA, L. I. ${ }^{2,3}$, RIBEIRO, L. F. C. ${ }^{4}$, \\ BRANCALHÃO, R. M. C. ${ }^{4}$ and BERTOLINI, G. R. F. ${ }^{5 *}$
}

\author{
${ }^{1}$ Universidade do Estado de Santa Catarina - UDESC, \\ Avenida Madre Benvenuta, 2007, Itacorubi, CEP 88035-001, Florianópolis, SC, Brazil \\ ${ }^{2}$ Universidade Estadual do Oeste do Paraná - UNIOESTE, \\ Rua Universitária, 2069, Jardim Universitário, CEP 85819-110, Cascavel, PR, Brazil \\ ${ }^{3}$ Universidade Federal do Paraná - UFPR, Rua XV de Novembro, 1299, Centro, \\ CEP 80060-000, Curitiba, PR, Brazil \\ ${ }^{4}$ Programa de Pós-Graduação em Biociências e Saúde, Laboratório de Biologia Celular, \\ Universidade Estadual do Oeste do Paraná - UNIOESTE, Rua Universitária, 2069, \\ Jardim Universitário, CEP 85819-110, Cascavel, PR, Brazil \\ ${ }^{5}$ Mestrado em Biociências e Saúde, Laboratório de Estudo das Lesões e \\ Recursos Fisioterapêuticos, Universidade Estadual do Oeste do Paraná - UNIOESTE, \\ Rua Universitária, 2069, Jardim Universitário, CEP 85819-110, Cascavel, PR, Brazil \\ ${ }^{*}$ E-mail: gladson_ricardo@yahoo.com.br
}

\begin{abstract}
Introduction: The aim of this study was to evaluate histomorphometrically two protocols of aquatic exercise on soleus of rats immobilized in dorsiflexion. Material and Methods: It was used 30 Wistar rats, randomly distributed in five groups: Gl - right hindlimb immobilized in maximum dorsiflexion, for 15 consecutive days, after this the animals were euthanized; G2 - also immobilized in maximum dorsiflexion, for 15 consecutive days, then the animals were freely remobilized; G3 - submitted to remobilization by free swim; G4 - submitted to remobilization with overload of $10 \%$ of body weight; G5 - remobilization by jumping in water with overload of $50 \%$ of body weight. The immobilization model used was made by plaster cast directly in the lower right limb of each animal. After removing the immobilization, the animals were submitted to remobilization for 10 days according to the group. At the end of the remobilization, the right and left soleus muscles were isolated, cleaned and weighed on an analytical balance, each muscle was sectioned longitudinally, and the medial part was used to evaluation of longitudinal parameters and the medial for cross-sectional assessment. Results: for the estimate of sarcomeres in series, muscular and sarcomere length there were not significant differences. For the muscle mass and fibers diameter there were difference between right and left soleus, but not for the groups. Conclusion: the used protocol of immobilization/remobilization was insufficient to cause changes in the overall longitudinal soleus, but the immobilization produced reduced mass and diameter of the fibers, which are not reversed with remobilization protocols.
\end{abstract}

Keywords: skeletal muscle, immobilization, physical exercise.

\section{Introduction}

The skeletal muscle is about $40 \%$ of body weight, allows precise movements and has great plasticity, which allows adjustment in accordance with the sustained stimulus. An increase in the mechanical load directs hypertrophy, while removal takes atrophy, decreasing the cross-sectional area of muscle fibers, while reducing the entire volume and muscle mass (BROOKS and MYBURGH, 2014), which can be seen in models of peripheral nerve injury (BERTOLINI, ARTIFON, SILVA et al., 2012) and immobilization (CARON, DROUIN, DESROSIERS, 2009).

The immobilization causes changes in several tissues such as bone (JU, SONE, OHNARU et al., 2012), joint capsule (ANDO, SUDA, HAGIWARA et al., 2012), cartilage (PORTINHO, BOIN and BERTOLINI, 2008), skin (ALTINTAS, VOGT and ALTINTAS, 2014) and tendon (ARO, VIDAL, TOMIOSSO et al., 2008). But, despite being a resource used in various types of injuries, it is little used in lesions of skeletal muscle, being observed that 5 and 14 days of immobilization is no significant loss in strength and muscle tropism. Then the influence of immobilization on the muscle is considered a side effect (BROOKS and MYBURGH, 2014).

The sarcomeres in series number vary in response to chronic disturbance of length, as in cases of immobilization in shortened and / or elongated position. Once the muscle is immobilized in shortening, there is a decrease in the sarcomeres number, and contrary to this, when it is kept in a stretched position, the muscle increases in length by increasing of sarcomeres (SHAH, PETERS, JORDAN et al., 2001).

The exercises are widely used in order to recover the hypotrophy after immobilization, such as muscle stretching (CAÇÃO-BENEDINI, RIBEIRO, GOMES et al., 2013; KONNO, ALVES, BERTOLINI et al., 2008; ARTIFON, 
FERRARI, CUNHA et al., 2012; CUNHA, NASCIMENTO, ARTIFON et al., 2012), electrical stimulation (CARVALHO, SHIMANO and PICADO, 2008), concentric (NATALI, SILVA, CIENA et al., 2008) and eccentric treadmill exercises (BENEDINI-ELIAS, MORGAN, CORNACHIONE et al., 2014), and the aquatic environment exploited both for swimming (VOLPI, CASAROLLI, PUDELL et al., 2008) and for jumping exercises (SILVA, MEIRELES, NASCIMENTO et al., 2013). However, when assessing the soleus muscle, usually is used protocol shortening, although significant advances have occurred in understanding the mechanisms involved in the development of atrophy in muscles immobilized in the shortened position, is still little explored when the muscle is immobilized in position elongated (KELLEHER, GORDON, KIMBALL et al., 2014). Thus, the present study aimed to evaluate histomorphometrically two protocols of aquatic exercise on soleus of rats immobilized in dorsiflexion.

\section{Materials and Methods}

\subsection{Experimental groups}

This study consists of a quantitative experimental research, cross-sectional. 30 albino Wistar rats, male, aged $10 \pm 2$ weeks, obtained in the animal vivarium of the Universidade Estadual do Oeste do Paraná (Unioeste) were used. The animals were grouped and maintained in plastic polypropylene cages with access to water and feed ad libitum, room temperature controlled at $25^{\circ} \mathrm{C}$ and photoperiod light/dark of 12 hours. The study was conducted in accordance with International Standards on Ethics in Animal Experimentation and approved by the Ethics Committee on Animal Experimentation and Practical Classes Unioeste, protocol number 02711.

At the beginning of the experiment the animals were weighed and identified, after that the animals were divided into five groups randomly distributed, with 6 animals each:

- Gl: the animals in this group had the right hindlimb immobilized in maximum dorsiflexion, for 15 consecutive days, in order to keep the soleus muscle in a stretched position. After the immobilization period, the animals were euthanized and their muscles were removed;

- G2: the animals of this group were also immobilized in maximum dorsiflexion, for 15 consecutive days. After the immobilization period, the animals were freely remobilized, or loose in their cages without undergoing interventions;

- G3: submitted to immobilization, but after this period, the animals were subjected to remobilization by free swim, as swimming protocol;

- G4: submitted to immobilization, after this period, underwent remobilization similar to G3, but with overload of $10 \%$ of body weight;

- G5: submitted to immobilization with subsequent remobilization by jumping in water, according to exercise protocol with jumps.

\subsection{Immobilization protocol}

The immobilization model used in this study was based on the proposed by Matheus, Gomide, Oliveira et al. (2007). All groups had containing plaster cast directly in the lower right limb of each animal, and placed so that the hind paw of the rats remained at full dorsiflexion of the ankle, ie stretching position of the soleus muscle was maintained for 15 consecutive days. The animals were previously sedated with intraperitoneal injection of ketamine $(80 \mathrm{mg} / \mathrm{kg})$ and xylazine $(12 \mathrm{mg} / \mathrm{kg})$.

\subsection{Remobilization protocol}

After removing the immobilization, the animals of G2 were only placed in contact with water in order to ensure equal treatment between the experimental groups, minimizing different stress responses by the action of water contact.

The G3 animals were submitted to swimming in tank of $200 \mathrm{~L}$, circular, made of plastic, with a depth of $50 \mathrm{~cm}$, with the water temperature maintained between $31^{\circ}$ and $33{ }^{\circ} \mathrm{C}$, verified by thermometer Inconterm ${ }^{\circledR}$. For 10 consecutive days, 15 minutes per day for the first 5 days and 30 minutes for the next five days.

For G4 animals, the procedure was similar to that of G3; however, the animals had a $10 \%$ overload of body weight. To overload are used lead weights attached to a velcro strip, which has been positioned on the chest of the animal, aiming not impair the movement.

The G5 animals underwent daily jumps in aquatic environment with $50 \%$ overload of body mass. The protocol was 4 sets of 5 jumps each, with an interval of 3 minutes between each set, every day, for 10 days in the afternoon. The counting of repetitions occurred each time the animal was projected toward the surface of the water to breathe. Prior to training, all animals were weighed before exercise to be established so that the amount of weight used as overload.

\subsection{Histomorphometric analysis}

At the end of the remobilization, all animals were euthanized by decapitation in guillotine. Soon after, the right and left soleus muscles were isolated, cleaned and weighed on an analytical balance $\left(\right.$ Shimadzu $\left.{ }^{\circledR}\right)$. After removal they were clean and after three hours of fixation in $10 \%$ formalin, each muscle was sectioned longitudinally, and the medial part was fixed in a polystyrene plates at its maximum resting length, to be measured by caliper analog $\left(\right.$ Tecnolub $\left.^{\circledR}\right)$, and were then immersed in nitric acid $(30 \%)$, in which they remained for 72 hours in order to break connective tissue. Then were stored in glycerol solution $(50 \%)$, until the time of preparation of the slides.

After this procedure, the muscle was placed in a Petri dish, and with help of a magnifying glass $\left(\right.$ Micronal $\left.^{\circledR}\right) 5$ fibers were isolated from tendon to tendon, using tweezers with ultra-fine tips, and mounted on varnished histological slide. To perform the analysis a common light microscope $\left(\right.$ Olympus $\left.^{\circledR}\right)$ was used with a $40 x$ objective, which images were taken of the isolated muscle fibers, and digitized for analysis using Image-Pro ${ }^{\circledR}$ Plus3.0 program, which the counting of sarcomeres was taken over $50 \mu \mathrm{m}$ in the image on 6 nonconsecutive fields, totaling 300 micrometers. The calculation used to estimate the total number of sarcomeres in series in muscle was the simple rule of three.

With the lateral part of the soleus was performed the preparation of cross-section slides. The slides were stained with hematoxylin and eosin (HE), and made the reading of ordinary light optical microscope with 40x objective. Subsequently, 
the images were captured and digitized for analysis with the Image-Pro Plus 3.0 software. Image analysis was based on the lower diameter of 100 fibers per muscle (BRITO, CAMARGO FILHO, VANDERLEI et al., 2006).

\subsection{Statistical analysis}

Statistical analysis was performed with assessment of normality and subsequent comparisons with ANOVA mixed model in order to reduce errors due to excessive ratings. The level of significance was $5 \%$.

\section{Results}

For the length of the soleus at rest did not differ between groups, nor between sides $(\mathrm{F}(1 ; 23)=0.363, \mathrm{p}=0.552)$, which also occurred for the estimation of sarcomeres along the soleus $(\mathrm{F}(1,23)=0.117, \mathrm{p}=0.736)$, and the size of the sarcomere $(\mathrm{F}(1,23)=1.708, \mathrm{p}=0.204)$. For muscle mass, there were significant differences between sides $(\mathrm{F}(1,23)=40.782$, $\mathrm{p}<0.001)$, but not between groups. This fact was repeated for smaller diameter fibers $(\mathrm{F}(1,23)=14.570, \mathrm{p}=0.002)$ (Table 1$)$.

\section{Discussion}

In the present study we sought to evaluate the effect of exercise during the remobilization of soleus immobilized in a stretched position. Despite the exercise represent the most widely used physiological stimulus in skeletal muscles rehabilitation, the mechanisms responsible for muscle adaptation are not fully understood (CORNACHIONE, CAÇÃO-BENEDINI, SHIMANO et al., 2011).

According Goldspink (1977) there is an increased protein synthesis when the muscle is immobilized in the extended position. And Kelleher, Gordon, Kimball et al. (2014) reported that after 3 days of immobilization of hindlimbs in rats, there was mass gain and increased rate of protein synthesis in soleus immobilized in extension. Discordantly, in the present study protocol immobilization produced muscle atrophy, this was visualized by both the reduction in muscle mass and the diameter of the muscle fibers. This may have occurred because, despite immobilization in extended position, the lack of physical exercise may have prevented hypertrophy signaling via mTOR (KELLEHER, GORDON, KIMBALL et al., 2014), or induced atrophy via phosphorylation of cofilin and LIM kinase (KIM, KIM, LEE et al., 2014), and exercise in post-immobilization period was probably insufficient to reverse these pathways because no group showed differences, ie the remobilization protocols used were not effective for the recovery of tropism, independent of load used.

Conversely, Carvalho, Shimano and Picado (2008) using both static stretching as electrostimulation in triceps surae of rats immobilized, observed that for the latter, muscle contraction was sufficient to restore the properties stretching at the proportionality limit, stiffness, resilience, load at proportional limit, load and stretching at maximum limit, which has not happened for all variables when only the stretching was used.

In the present study we observed that swimming, independent of load, was unable to change the variables. Similarly Kodama, Camargo, Job et al. (2012) found that remobilization with swimming for 5 days, after 7 days of immobilization, was not sufficient to restore the mechanical properties, reducing the muscle's capacity to withstand loads. Concurrently, Nascimento, Padula, Milani et al. (2008) after a one week period of immobilization in trained rats (swimming and overhead for six weeks), they reported that swimming for two weeks without overloading but with increasing time, was not able to reverse the deleterious effects of immobilization. But Morimoto, Winaga, Sakurai et al. (2013) observed that after 2 weeks of immobilization, the walking exercise on a treadmill (12 m/min) for 2 weeks, 30 minutes per session, and static stretching for 10 minutes 3 times a week, were enough to improve the range of motion, muscle tropism and chronic pain after immobilization.

Cornachione, Cação-Benedini, Shimano et al. (2011) observed after hypokinesia protocol by raising the hindlimb in rats, the treadmill exercise improved the capillary/fiber ratio and capillary density, and increase in myosin isoform type I, especially when used concentric exercise protocol. In another study also reported that 21 days of treadmill exercise regained ratio fibers and their diameters, mainly downhill exercise protocols (CORNACHIONE, CAÇÃO-BENEDINI, SHIMANO et al., 2008). In our study besides swimming, jumping in water with overload, despite its intensity also did not produce differences in the variables, but even showed to be useful for the recovery of fiber diameter when the soleus was immobilized in a shortened position (SILVA, MEIRELES, NASCIMENTO et al., 2013).

Immobilization in a shortening position of the soleus produces significant reduction in muscle length and the estimate of

Table 1. Values obtained for the different groups (Gl-G5), for the variables: soleus length - SolL (cm), estimate of sarcomeres along the muscle - ESM, sarcomere length - SarcL $(\mu \mathrm{m})$, the soleus mass - SM (g) and average diameter of 100 fibers - DF ( $\mu \mathrm{m})$.

\begin{tabular}{|c|c|c|c|c|c|c|}
\hline & & SolL & ESM & SarcL & SM* & $\mathrm{DF}^{*}$ \\
\hline \multirow{2}{*}{ Gl } & $\mathrm{D}$ & $2.23 \pm 0.21$ & $10,877 \pm 1,276$ & $2.06 \pm 0.13$ & $0.125 \pm 0.032$ & $31.72 \pm 3.51$ \\
\hline & $\mathrm{E}$ & $2.09 \pm 0.21$ & $10,405 \pm 1,476$ & $2.02 \pm 0.12$ & $0.162 \pm 0.032$ & $35.37 \pm 2.03$ \\
\hline \multirow{2}{*}{ G2 } & $\mathrm{D}$ & $2.32 \pm 0.27$ & $10,614 \pm 1,290$ & $2.19 \pm 0.03$ & $0.104 \pm 0.006$ & $37.52 \pm 8.87$ \\
\hline & $\mathrm{E}$ & $2.15 \pm 0.16$ & $10,322 \pm 1,018$ & $2.09 \pm 0.09$ & $0.150 \pm 0.012$ & $48.81 \pm 14.29$ \\
\hline \multirow{2}{*}{ G3 } & $\mathrm{D}$ & $1.93 \pm 0.23$ & $9,153 \pm 1,219$ & $2.12 \pm 0.05$ & $0.094 \pm 0.010$ & $35.41 \pm 8.85$ \\
\hline & $\mathrm{E}$ & $2.10 \pm 0.24$ & $10,018 \pm 1,201$ & $2.10 \pm 0.12$ & $0.152 \pm 0.020$ & $54.07 \pm 12.09$ \\
\hline \multirow{2}{*}{ G4 } & $\mathrm{D}$ & $2.05 \pm 0.25$ & $9,409 \pm 951$ & $2.18 \pm 0.15$ & $0.106 \pm 0.018$ & $34.35 \pm 2.99$ \\
\hline & $\mathrm{E}$ & $2.13 \pm 0.12$ & $9,590 \pm 867$ & $2.23 \pm 0.13$ & $0.157 \pm 0.021$ & $38.09 \pm 9.25$ \\
\hline \multirow{2}{*}{ G5 } & $\mathrm{D}$ & $2.01 \pm 0.24$ & $9,211 \pm 1,171$ & $2.19 \pm 0.10$ & $0.086 \pm 0.010$ & $30.49 \pm 2.61$ \\
\hline & $\mathrm{E}$ & $1.94 \pm 0.33$ & $9,377 \pm 1,493$ & $2.07 \pm 0.14$ & $0.1296 \pm 0.011$ & $51.33 \pm 17.37$ \\
\hline
\end{tabular}

* Signficant difference between the right and left sides. 
sarcomeres in series (KONNO, ALVES, BERTOLINI et al., 2008; NATALI, SILVA, CIENA et al., 2008; VOLPI, CASAROLLI, PUDELL et al., 2008) and even changes in sarcomere length (KONNO, ALVES, BERTOLINI et al., 2008; NATALI, SILVA, CIENA et al., 2008). In the model used in the present study no change was observed in the longitudinal variables, thus we believed that the form of immobilization may have been a major limitation, because despite producing immobility, installed easily observed by hypotrophy, may not have been sufficient to maintaining full ankle dorsiflexion.

\section{Conclusion}

The used protocol of immobilization/remobilization was insufficient to cause changes in the overall longitudinal soleus, but the immobilization produced reduced mass and diameter of the fibers, which are not reversed with remobilization protocols.

Acknowledgements: To the Conselho Nacional de Desenvolvimento Científico e Tecnológico (CNPq) and the Universidade Estadual do Oeste do Paraná, for grants for scientific initiation.

\section{References}

ALTINTAS, AA., VOGT, PM. and ALTINTAS, MA. Acute effects of splint immobilization of the forearm on in vivo microcirculation and histomorphology of the human skin. Microscopy Research and Technique, 2014, vol. 77, n. 1, p. 99-103. http://dx.doi.org/10.1002/ jemt.22317. PMid:24738150.

ANDO, A., SUDA, H., HAGIWARA, Y., ONODA, Y., CHIMOTO, E. and ITOI, E. Remobilization does not restore immobilization-induced adhesion of capsule and restricted joint motion in rat knee joints. The Tohoku Journal of Experimental Medicine, 2012, vol. 227, n. 1, p. 13-22. http://dx.doi.org/10.1620/tjem.227.13. PMid:22510696.

ARO, AA., VIDAL, BC., TOMIOSSO, TC., GOMES, L., MATIELLOROSA, SM. and PIMENTEL, ER. Structural and biochemical analysis of the effect of immobilization followed by stretching on the calcaneal tendon of rats. Connective Tissue Research, 2008, vol. 49, n. 6, p. 443-454. http://dx.doi.org/10.1080/03008200802325250. PMid:19085245.

ARTIFON, EL., FERRARI, D., CUNHA, DM., NASCIMENTO, CM., RIBEIRO, LFC. and BERTOLINI, GRF. Efeitos do ultrassom terapêutico associados ao alongamento estático sobre parâmetros histomorfométricos longitudinais de sóleos imobilizados de ratos. Revista Brasileira de Medicina do Esporte, 2012, vol. 18, n. 5, p. 341-344. http://dx.doi.org/10.1590/S1517-86922012000500012.

BENEDINI-ELIAS, PCO., MORGAN, MC., CORNACHIONE, AS., MARTINEZ, EZ. and MATTIELLO-SVERZUT, AC. Postimmobilization eccentric training promotes greater hypertrophic and angiogenic responses than passive stretching in muscles of weanling rats. Acta Histochemica, 2014, vol. 116, n. 3, p. 503-513. http:// dx.doi.org/10.1016/j.acthis.2013.10.008. PMid:24304683.

BERTOLINI, GRF., ARTIFON, EL., SILVA, LI., RIBEIRO, LFC. and BRANCALHÃO, RMC. Avaliação do trofismo muscular de sóleos de ratos wistar após compressão nervosa e tratamento. Revista Brasileira de Ciências do Esporte, 2012, vol. 34, n. 4, p. 1035-1046. http://dx.doi.org/10.1590/S0101-32892012000400016.

BRITO, MKM., CAMARGO FILHO, JCS., VANDERLEI, LCM., TARUMOTO, MH., DAL PAI, V. and GIACOMETTI, JA. Dimensões geométricas das fibras do músculo sóleo de ratos exercitados em esteira rolante: a importância da análise por meio de imagens digitalizadas. Revista Brasileira de Medicina do Esporte, 2006, vol. 12, n. 2, p. $103-$ 107. http://dx.doi.org/10.1590/S1517-86922006000200010.
BROOKS, NE. and MYBURGH, KH. Skeletal muscle wasting with disuse atrophy is multi-dimensional: the response and interaction of myonuclei, satellite cells and signaling pathways. Frontiers in Physiology, 2014, vol. 5, p. 99. PMid:24672488.

CAÇÃO-BENEDINI, LO., RIBEIRO, PG., GOMES, ARS., YWAZAKI, JL., MONTE-RASO, VV., PRADO, MC. and MATTIELLO-SVERZUT, AC. Remobilization through stretching improves gait recovery in the rat. Acta Histochemica, 2013, vol. 115, n. 5, p. 460-469. http:// dx.doi.org/10.1016/j.acthis.2012.11.001. PMid:23265777.

CARON, AZ., DROUIN, G., DESROSIERS, J., TRENSZ, F. and GRENIER, G. A novel hindlimb immobilization procedure for studying skeletal muscle atrophy and recovery in mouse. Journal of Applied Physiology, 2009, vol. 106, n. 6, p. 2049-2059. http:// dx.doi.org/10.1152/japplphysiol.91505.2008. PMid:19342435.

CARVALHO, LC., SHIMANO, AC. and PICADO, CHF. Estimulação elétrica neuromuscular e o alongamento passivo manual na recuperação das propriedades mecânicas do músculo. Acta Ortopedica Brasileira, 2008, vol. 16, n. 3, p. 161-164. http://dx.doi.org/10.1590/S141378522008000300007 .

CORNACHIONE, A., CAÇÃO-BENEDINI, LO., SHIMANO, MM., VOLPON, JB., MARTINEZ, EZ. and MATTIELLO-SVERZUT, AC. Morphological comparison of different protocols of skeletal muscle remobilization in rats after hindlimb suspension. Scandinavian Journal of Medicine e Science in Sports, 2008, vol. 18, n. 4, p. 453-461. http:// dx.doi.org/10.1111/j.1600-0838.2007.00720.x. PMid:18067520.

CORNACHIONE, A., CAÇÃO-BENEDINI, LO., MARTINEZ, EZ., NEDER, L. and CLÁUDIA MATTIELLO-SVERZUT, A. Effects of eccentric and concentric training on capillarization and myosin heavy chain contents in rat skeletal muscles after hindlimb suspension. Acta Histochemica, 2011, vol. 113, n. 3, p. 277-282. http://dx.doi.org/10.1016/j.acthis.2009.10.009. PMid:20153026.

CUNHA, DM., NASCIMENTO, CM., ARTIFON, EL., FERRARI, D., RIBEIRO, LFC., FONTANESI, LB. and BERTOLINI, GRF. Evaluation of rats' soleus muscle submitted to remobilization protocol with therapeutic ultrasound associated with static stretching. Journal of Morphological Sciences, 2012, vol. 29, n. 1, p. 53-57.

GOLDSPINK, DF. The influence of immobilization and stretch on protein turnover of rat skeletal muscle. The Journal of Physiology, 1977, vol. 264, n. 1, p. 267-282. http://dx.doi.org/10.1113/ jphysiol.1977.sp011667. PMid:839454.

JU, YI., SONE, T., OHNARU, K., CHOI, HJ. and FUKUNAGA, M. Differential effects of jump versus running exercise on trabecular architecture during remobilization after suspension-induced osteopenia in growing rats. Journal of Applied Physiology, 2012, vol. 112, n. 5, p. 766-772. http://dx.doi.org/10.1152/japplphysiol.01219.2011. PMid:22162526.

KELLEHER, AR., GORDON, BS., KIMBALL, SR. and JEFFERSON, LS. Changes in REDD1, REDD2, and atrogene mRNA expression are prevented in skeletal muscle fixed in a stretched position during hindlimb immobilization. Physiological Reports, 2014, vol. 2, n. 2, p. e00246. http://dx.doi.org/10.1002/phy2.246. PMid:24744910.

KIM, MY., KIM, JH., LEE, JU., LEE, LK., YANG, SM., JEON, HJ., LEE, WD., NOH, JW., LEE, TH., KWAK, TY., KIM, B. and KIM, J. Decrease of both cofilin and LIM kinase phosphorylation in the skeletal muscles of immobilization-induced atrophy rats. Journal of Physical Therapy Science, 2014, vol. 26, n. 3, p. 355-357. http:// dx.doi.org/10.1589/jpts.26.355. PMid:24711688.

KODAMA, FY., CAMARGO, RCT., JOB, AE., OZAKI, GAT., KOIKE, TE. and CAMARGO FILHO, JCS. Muscle mechanical properties of adult and older rats submitted to exercise after immobilization. Acta Ortopedica Brasileira, 2012, vol. 20, n. 4, p. 218-222. http:// dx.doi.org/10.1590/S1413-78522012000400005. PMid:24453606.

KONNO, EAB., ALVES, ÉPB., BERTOLINI, GRF., BARBIERI, CH. and MAZZER, N. Remobilização por alongamento estático cíclico 
em músculo sóleo de ratos imobilizados em encurtamento. Revista Brasileira de Medicina do Esporte, 2008, vol. 14, n. 2, p. 122-125. http://dx.doi.org/10.1590/S1517-86922008000200008.

MATHEUS, JPC., GOMIDE, LB., OLIVEIRA, JGP., VOLPON, JB. and SHIMANO, AC. Efeitos da estimulação elétrica neuromuscular durante a imobilização nas propriedades mecânicas do músculo esquelético. Revista Brasileira de Medicina do Esporte, 2007, vol. 13 , n. 34 , p. 55-59

MORIMOTO, A., WINAGA, H., SAKURAI, H., OHMICHI, M., YOSHIMOTO, T., OHMICHI, Y., MATSUI, T., USHIDA, T. OKADA, T. and SATO, J. Treadmill running and static stretching improve long-lasting hyperalgesia, joint limitation, and muscle atrophy induced by cast immobilization in rats. Neuroscience Letters, 2013, vol. 534, p. 295-300. http://dx.doi.org/10.1016/j.neulet.2012.11.009. PMid:23153829.

NASCIMENTO, CCF., PADULA, N., MILANI, JGPO., SHIMANO, AC., MARTINEZ, EZ. and MATTIELLO-SVERZUT, AC. Histomorphometric analysis of the response of rat skeletal muscle to swimming, immobilization and rehabilitation. Brazilian Journal of Medical and Biological Research, 2008, vol. 41, n. 9, p. 818824. http://dx.doi.org/10.1590/S0100-879X2008000900013. PMid:18820773.

NATALI, LH., SILVA, TS., CIENA, AP., PADOIN, MJ., ALVES, ÉPB., ARAGÃO, FA. and BERTOLINI, GRF. Efeitos da corrida em esteira em músculos sóleos de ratos encurtados por imobilização. Revista Brasileira de Medicina do Esporte, 2008, vol. 14, n. 6, p. 490493. http://dx.doi.org/10.1590/S1517-86922008000600003.
PORTINHO, D., BOIN, VG. and BERTOLINI, GRF. Efeitos sobre o tecido ósseo e cartilagem articular provocados pela imobilização e remobilização em ratos Wistar. Revista Brasileira de Medicina do Esporte, 2008, vol. 14, n. 5, p. 408-411. http://dx.doi.org/10.1590/ S1517-86922008000500001.

SHAH, SB., PETERS, D., JORDAN, KA., MILNER, DJ., FRIDÉN, J., CAPETANAKI, Y. and LIEBER, RL. Sarcomere number regulation maintained after immobilization in desmin-null mouse skeletal muscle. The Journal of Experimental Biology, 2001, vol. 204, n. 10, p. 17031710. PMid:11316490.

SILVA, LI., MEIRELES, A., NASCIMENTO, CM., ROCHA, BP., ROSA, CT., RIBEIRO, LFC., BRANCALHÃO, RMC. and BERTOLINI, GRF. Avaliação de parâmetros histomorfométricos em sóleos de ratos submetidos à remobilização por salto em meio aquático. Revista Brasileira de Medicina do Esporte, 2013, vol. 19, n. 3, p. 219 222. http://dx.doi.org/10.1590/S1517-86922013000300015.

VOLPI, FS., CASAROLLI, LM., PUDELL, C., MENON, T., CIENA, AP., ALVES, ÉPB. and BERTOLINI, GRF. Efeitos da remobilização em duas semanas com natação sobre o músculo sóleo de ratos submetidos à imobilização. Revista Brasileira de Medicina do Esporte, 2008, vol. 14, n. 3, p. 168-170. http://dx.doi.org/10.1590/ S1517-86922008000300001.
Received May 23, 2014

Accepted September 5, 2015 